Research Article

\title{
Effect of Deposition Conditions on Phase Content and Mechanical Properties of Yttria-Stabilized Zirconia Thin Films Deposited by Sol-Gel/Dip-Coating
}

\author{
Francisco J. Cano, ${ }^{1}$ Orlando Castilleja-Escobedo, ${ }^{1}$ L. J. Espinoza-Pérez, ${ }^{1,2}$ \\ Cecilia Reynosa-Martínez, ${ }^{1}$ and Eddie Lopez-Honorato $\mathbb{1}^{1,3}$ \\ ${ }^{1}$ Centro de Investigación y de Estudios Avanzados del IPN (CINVESTAV), Avenida Industria Metalúrgica 1062, Ramos Arizpe, \\ Coahuila 25900, Mexico \\ ${ }^{2}$ Universidad Nacional de Ingenieria (UNI), Sede Central, Avenida Universitaria, 5595 Managua, Nicaragua \\ ${ }^{3}$ Oak Ridge National Laboratory, Oak Ridge, TN 37831, USA
}

Correspondence should be addressed to Eddie Lopez-Honorato; honoratole@ornl.gov

Received 11 May 2021; Revised 16 September 2021; Accepted 27 September 2021; Published 13 October 2021

Academic Editor: Domenico Acierno

Copyright (c) 2021 Francisco J. Cano et al. This is an open access article distributed under the Creative Commons Attribution License, which permits unrestricted use, distribution, and reproduction in any medium, provided the original work is properly cited.

\begin{abstract}
The effect of yttria concentration (0-33.4 mol\%), extraction rates $\left(0.17,0.33,0.50\right.$, and $\left.0.67 \mathrm{~mm} \mathrm{~s}^{-1}\right)$, and the number of layers (up to four) on the phase content, surface defects, thickness, hardness, adhesion strength, and wear rate of yttria-stabilized zirconia coatings produced by sol-gel/dip-coating were studied for its use on thermolabile substrates. At $700^{\circ} \mathrm{C}$, a metastable tetragonal phase $\left(t^{\prime \prime}\right)$ was obtained even with $33.4 \mathrm{~mol} \%$ yttria when heat treated for 24 hours; however, a fully cubic structure was attained by extending the heat treatment up to 48 hours as confirmed by Raman spectroscopy. Furthermore, it was necessary to use withdrawal speeds of at least $0.67 \mathrm{~mm} \mathrm{~s}^{-1}$ to produce defect-free coatings. Although the coatings were produced at low temperature, they showed $41 \%$ lower wear rate than steel and an adhesion strength of $30 \mathrm{MPa}$. Our work stresses the importance of the heat treatment history on the stabilization of the cubic phase in sol-gel YSZ coatings.
\end{abstract}

\section{Introduction}

Yttria-stabilized zirconia (YSZ) due to its low thermal conductivity, chemical inertness, radiation resistance, and high mechanical properties has been proposed for a wide range of applications in the nuclear industry, such as inert matrix fuel, diffusion barrier to avoid fuel-matrix interaction, sacrificial coatings, and thermal insulator, among others [1-6]. However, some of these applications require the deposition of YSZ at low temperatures (for example, $1050^{\circ} \mathrm{C}$ on T91 steel or $800^{\circ} \mathrm{C}$ on Ni alloys) to avoid phase changes or considerable reductions on mechanical properties on thermolabile substrates $[3,7,8]$. In addition to this requirement, for nuclear applications, the production of YSZ with a fully cubic structure is also desirable to increase its tolerance to neutron irradiation [9-12].
Overall, among the different deposition techniques available to deposit YSZ, sol-gel/dip-coating is comparatively simple, cost-effective, and capable of producing coatings at low temperatures [13]. However, a common feature associated with the deposition of YSZ thin films and coatings through sol-gel/dip-coating is the production of materials with cracks or defects if the heat treatment or deposition conditions are not controlled [3, 14-16]. For example, it has been observed that coatings thicker than $200 \mathrm{~nm}$ are prone to cracking due to the release of gases, thermal mismatch between the coating and the substrate, and internal stresses during heat treatment [17-19]. Crack formation can be reduced or avoided by controlling the sol-gel fabrication route (for example, using complexing agents affecting the hydrolysis and condensation reactions or by modifying the viscosity of the gel), the extraction rate, and heat 
treatment temperature or by depositing several consecutive coatings for the purpose of filling the cracks that are generated [14, 16, 19-21]. Higher heat treatment temperatures tend to reduce the formation of cracks, whereas the deposition of a multilayer system can result in coatings with lower wear life and reduced performance at high temperature due to a weak bonding between each film $[22,23]$. Furthermore, some reports have shown that the cubic phase, needed for nuclear applications, is not favorable below $800^{\circ} \mathrm{C}$, resulting in the formation of a tetragonal phase even with $18.2 \mathrm{~mol} \%$ yttria at $1150^{\circ} \mathrm{C}$ due to the limited diffusion at those low temperatures $[16,21,24]$. Therefore, it is important to study the production of YSZ at low temperatures to obtain defect free, fully cubic, and mechanical resistant structures.

This work describes the production of YSZ thin films at $700^{\circ} \mathrm{C}$, showing that the tetragonal phase $\left(t^{\prime}\right.$ and $\left.t^{\prime \prime}\right)$ was maintained even with concentration up to $33.4 \mathrm{~mol} \%$ yttria after $24 \mathrm{~h}$ of sintering. A fully cubic structure was achieved only after 48 hours of heat treatment with 29.0 and $33.4 \mathrm{~mol} \% \mathrm{yttria}$, as confirmed by X-ray diffraction (XRD) and Raman spectroscopy. Additionally, it was feasible to produce defect-free film layers up to $824 \mathrm{~nm}$ thick by controlling the extraction rate during dip-coating. Finally, contrary to previous reports, we show that a multilayer YSZ coating system sintered at $700^{\circ} \mathrm{C}$ produced an increase in hardness and wear resistance of 93 and $42 \%$ compared to steel, respectively, by maintaining an adhesion strength of $30 \mathrm{MPa}$.

\section{Materials and Methods}

Yttria-stabilized zirconia (YSZ) coatings were deposited on $2 \times 1 \mathrm{~cm}^{2}$ stainless steel 304 substrates. These substrates were ground with abrasive $\mathrm{SiC}$ paper and then polished with 3 and $1 \mu \mathrm{m}$ diamond paste. Finally, the samples were immersed in an ultrasound bath with Citranox and then in an ethanol/acetone solution.

An initial solution was prepared by mixing $27.4 \mathrm{ml}$ of zirconium n-propoxide (ZNP) (70\% by weight in isopropanol, Sigma-Aldrich), $35.6 \mathrm{ml}$ of ethanol (99.8\%, Vetec), and $3.8 \mathrm{ml} \mathrm{HNO}_{3}$ (6.3\%, JT Baker) under argon atmosphere and constant stirring $(300 \mathrm{rpm})$. After 6 hours, a mixture of $7.7 \mathrm{ml}$ of distilled water and $2.7 \mathrm{ml}$ of acetic acid $(99.7 \%$, Jalmek) (weight ratio $3: 1$ ) was added. The molar ratios used for these solutions were 10:1 for ethanol:ZNP, 6.6:1 for isopropanol:ZNP, and 7:1 for $\mathrm{H}_{2} \mathrm{O}: \mathrm{ZNP}$. A second solution was prepared with $6.7 \mathrm{~g}$ of yttrium acetate $(99.9 \%$, Sigma-Aldrich), $9.2 \mathrm{ml}$ of isopropanol (99.5\%, from Jalmek), and $10 \mathrm{ml}$ of $\mathrm{HNO}_{3}$ (this last one added drop by drop until the solution became transparent), maintaining the solution stirred for $1 \mathrm{~h}$ at $300 \mathrm{rpm}$ to obtain a $29 \mathrm{~mol} \%$ of $\mathrm{YO}_{1.5}$ (29YSZ). Similar solutions were prepared, this time modifying the amount of yttrium acetate in order to achieve a mol percentage of $7.6,11.4,14.8,18.2$, and $33.4 \% \mathrm{~mol}$ of $\mathrm{YO}_{1.5}$.

The coatings were obtained using a dip-coater (WPTL60.01 MTI Corporation) by introducing the samples to the gel for 60 seconds and varying the extraction rates at $0.17,0.33$, 0.50 , and $0.67 \mathrm{~mm} \mathrm{~s}^{-1}$. After extraction, samples were dried in air at room temperature for 24 hours and then at $500^{\circ} \mathrm{C}$ for 2 hours (using a heating/cooling rate of $1^{\circ} \mathrm{C} / \mathrm{min}$ ). The previous procedure was repeated between each deposition in multilayered coatings (up to 4 layers) before the final heat treatment at $700^{\circ} \mathrm{C}$ in air for 24 or $48 \mathrm{~h}$ (using a heating/cooling rate of $10^{\circ} \mathrm{C} / \mathrm{min}$ ). After this final heat treatment, the microstructure and mechanical properties of the coatings were characterized.

YSZ with 29.0 (29YSZ) and $33.4 \mathrm{~mol} \%$ of yttria (33.4YSZ) were characterized by thermogravimetric analysis under air atmosphere, using a thermal analyzer instrument (TA Instruments, SDT Q600), with a heating rate of $10^{\circ} \mathrm{C} / \mathrm{min}$. The microstructure of the coatings was characterized by scanning electron microscopy (SEM), using a Philips XL30 microscope using an accelerating voltage of $20 \mathrm{kV}$. The composition was characterized by energy-dispersive X-ray spectroscopy (EDS). The phase content of YSZ powders obtained after the heat treatment of the solutions was characterized by X-ray diffraction (XRD) (PANalytical Empyrean) in the regions $10^{\circ} \leq 2 \theta \leq 80^{\circ}$ and $71^{\circ} \leq 2 \theta \leq 76^{\circ}$, using a step size of $0.03^{\circ}$ and $3 \mathrm{~s}$ per step, with a $\mathrm{CuK} \alpha$ radiation of $1.542 \AA$ wavelength. The crystallite size was calculated from the (111) plane at $30^{\circ}$ using the Scherrer formula.

$$
D(\mathrm{~nm})=\frac{0.89 \lambda}{\mathrm{FWHM} \operatorname{Cos} \theta},
$$

where $D$ is the crystallite size in $\mathrm{nm}, \lambda$ the $\mathrm{X}$-ray wavelength, FWHM the full-width at half maximum of the diffraction peak, and $\theta$ the diffraction-peak angle. The lattice parameters $(c$ and $a$ ) were obtained using the software MDI Jade 6. The tetragonality factor $(c / \sqrt{2} a)$ was used to identify the metastable tetragonal $\left(t^{\prime}\right.$ and $\left.t^{\prime \prime}\right)$ or cubic phases [24, 25]. Additionally, Raman spectroscopy (Renishaw inVia) was also used to characterize the phase content using a $514 \mathrm{~nm}$ wavelength laser, and a 50x lens obtaining a spot size of approximately $5 \mu \mathrm{m}$.

The thickness of each layer was measured by profilometry using a KLA Tencor D-600 profilometer. The hardness of the coatings was evaluated by indentation using the ASTM C1327-08 Norm, using Shimadzu G21 series equipment with a Vickers indenter and applying a load of 25 gramsforce. The adhesion strength was determined by Pull-Off tests based on the ASTM D4541-09 method using a universal testing machine MTS QTest/100 equipment. Finally, abrasion resistance was determined using a Pin-on-Disk Tribometer (Microtest MT Series), using the ASTM G9995 a method, with a load of $10 \mathrm{~N}$, a ball of steel Al-chrome of $4 \mathrm{~mm}$ diameter, a distance of $20 \mathrm{~m}$, and a speed of $30 \mathrm{rpm}$.

\section{Results and Discussion}

3.1. Effect of Yttria Concentration and Sintering Time. Figure 1 shows the thermogravimetric analysis of YSZ produced with $29 \mathrm{~mol} \%$ yttria (29YSZ). Overall, three different stages in the transformation of YSZ were observed. In stage I, which ranged from room temperature up to approximately $220^{\circ} \mathrm{C}$, a weight loss of $\sim 15 \%$ was observed. This weight loss has been associated with the vaporization of superficial and structural water [19, 25-28]. The stage II, 


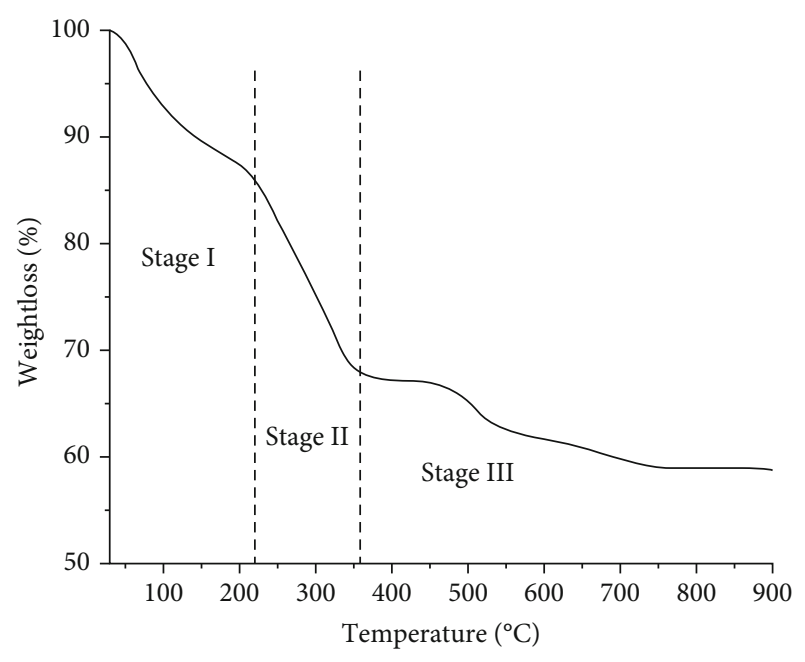

FIGURE 1: TGA curve of YSZ with $29 \mathrm{~mol}^{\mathrm{O}} \mathrm{YO}_{1.5}$ (29YSZ).

which ranges from 220 to $350^{\circ} \mathrm{C}$, with a weight loss of $19 \%$, has been associated with the combustion and decomposition of organic compounds [19, 26, 28-30]. The stage III, above $350^{\circ} \mathrm{C}$, accompanied by a final weight loss of $10 \%$, has been correlated with the decomposition of nitrates originated from the nitric acid [29], as well as the beginning of the crystallization of YSZ [30]. A similar behavior was observed for YSZ with $33.4 \mathrm{~mol} \%$ yttria (33.4YSZ) in Figure S1 (supplementary material).

Figure 2 shows the X-ray diffraction patterns obtained for the zirconia powders doped with different yttria concentration $\left(0-33.4 \mathrm{~mol} \% \mathrm{YO}_{1.5}\right)$ and heat treated at $700^{\circ} \mathrm{C}$ for $24 \mathrm{~h}$. The zirconia synthesized without any dopant (OYSZ) showed the characteristic reflections of both the monoclinic $(m)$ and tetragonal $(t)$ phases. On the other hand, zirconia powders doped with 7.6-33.4 mol\% $\mathrm{YO}_{1.5}$ showed the reflection characteristic of the tetragonal $(t)$ and/or cubic $(c)$ phase. Moreover, Table 1 shows that, at $700^{\circ} \mathrm{C}$, the increase in the molar content of $\mathrm{YO}_{1.5}$ from 7.6 to 33.4 caused a decrease in the crystallite size from 13.2 to $6.1 \mathrm{~nm}$, respectively, i.e., the crystal growth was inhibited by the increase in the yttria content. This behavior has been correlated to the segregation of yttria at the grain boundaries, decreasing the mass transfer by surface diffusion and avoiding the crystal growth $[31,32]$. Furthermore, it has been reported that higher concentrations of yttria change the crystallization temperature to higher values, retarding the crystal growth [33]. Similarly, inhibition of crystal growth has been reported in zirconia systems doped with aluminum and europium $[34,35]$. The occurrence of the tetragonal zirconia at room temperature and without the use of any dopant in sample 0YSZ could due to the crystallite size, which is below the critical crystallite size of around $30 \mathrm{~nm}$, below which the tetragonal phase can exist at low temperatures due to a larger specific surface area and an excess of energy [36].

Although generally the tetragonal phase could be differentiated from the cubic phase due to the presence of doublets in the diffraction pattern in angles below $70^{\circ}$, the broadening of the signals due to small crystallite sizes (see Table 1), particularly at low sintering temperatures, makes

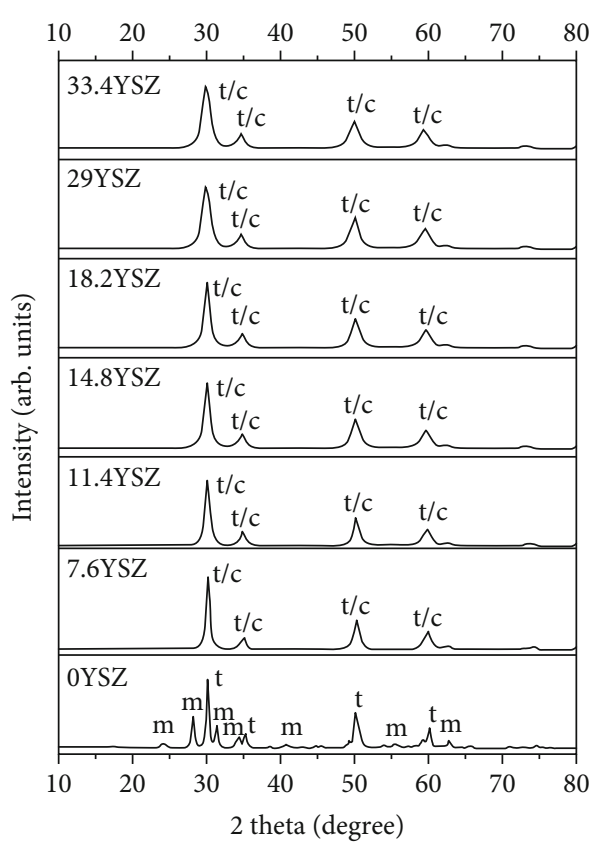

FIGURE 2: XRD patterns of zirconia powders doped with 0-33.4 mol\% $\mathrm{YO}_{1.5}$, heat treated at $700^{\circ} \mathrm{C}$ for $24 \mathrm{~h}$, region $10^{\circ} \leq 2 \theta \leq 80^{\circ}$.

this differentiation by simple observation unpractical [37, 38]. Therefore, a more detailed analysis was performed using the diffractograms between 71 and $76^{\circ}$ (Figure 3) and the tetragonality factor $c / \sqrt{2} a$ in Table 1 .

Figure 3 shows the diffraction patterns between 71 and $76^{\circ}$. The $7.6 \mathrm{~mol} \%$ yttria powders had signals at $73^{\circ}$ and $74.5^{\circ}$, which are characteristics of the tetragonal phase [37], whereas at $11.4 \mathrm{~mol} \%$, an asymmetric diffraction pattern centered at $74^{\circ}$ was observed, likely due to a mixture of tetragonal and cubic/metastable tetragonal phase $\left(t^{\prime \prime}\right)$ [37]. Above $18.2 \mathrm{~mol} \%$ yttria, the diffraction patterns could suggest the formation of a fully cubic structure. However, Yashima et al. have suggested the existence of a metastable tetragonal phase $t^{\prime \prime}$, which differentiates from the cubic phase due to a slight distortion of the anionic network [24, 38]. The presence of the tetragonal (transformable, nontransformable, and metastable: $t, t^{\prime}$, and $t^{\prime \prime}$, respectively) or cubic phases could be differentiated based on their tetragonality, where a tetragonality of 1 would suggest a cubic or $t^{\prime \prime}$ phase $[24,25]$.

Table 1 shows that the tetragonality decreased from 1.0059 to 1.0000 as the molar concentration of yttria increased from 7.6 to $33.4 \mathrm{~mol} \%[24,38,39]$. According to the relationship between tetragonality and phase content suggested by Viazzi et al. [38], zirconia powders with yttria contents between 7.6 and $18.2 \mathrm{~mol} \%$ developed a nontransformable tetragonal phase $\left(t^{\prime}\right)$, while the tetragonal metastable $\left(t^{\prime \prime}\right)$ or cubic phase (c) could be assigned to zirconia powders with an yttria content between 29 and $33.4 \mathrm{~mol} \%$ [38].

Raman spectroscopy was used to further characterize the YSZ produced since Raman spectroscopy is highly sensitive to phase transitions induced by oxygen displacement, even without a long-range periodicity $[40,41]$. Figure 4 shows 
TABLE 1: Crystallite size, lattice parameters, and tetragonality factor for zirconia powders doped with 7.6-33.4 mol\% yttria, heat treated at $700^{\circ} \mathrm{C}$ for $24 \mathrm{~h}$.

\begin{tabular}{lcccccc}
\hline Nomenclature & $\mathrm{YO}_{1.5}$ content $(\mathrm{mol} \%)$ & Crystallite size $(\mathrm{nm})$ & $a(\AA)$ & $c(\AA)$ & $c / \sqrt{2} a$ & Phase \\
\hline 7.6YSZ & 7.6 & 13.2 & 3.6181 & 5.1471 & 1.0059 & $t^{\prime}$ \\
$11.4 \mathrm{YSZ}$ & 11.4 & 10.1 & 3.6288 & 5.1398 & 1.0015 \\
$14.8 \mathrm{YSZ}$ & 14.8 & 8.9 & 3.6306 & 5.1389 & 1.0009 \\
$18.2 \mathrm{YSZ}$ & 18.2 & 7.5 & 3.6366 & 5.1456 & 1.0005 \\
29YSZ & 29.0 & 6.4 & 3.6392 & 5.1464 & 1.0000 & $t^{\prime}$ \\
$33.4 \mathrm{YSZ}$ & 33.4 & 6.1 & 3.6540 & 5.1530 & 1.0000 \\
\hline
\end{tabular}

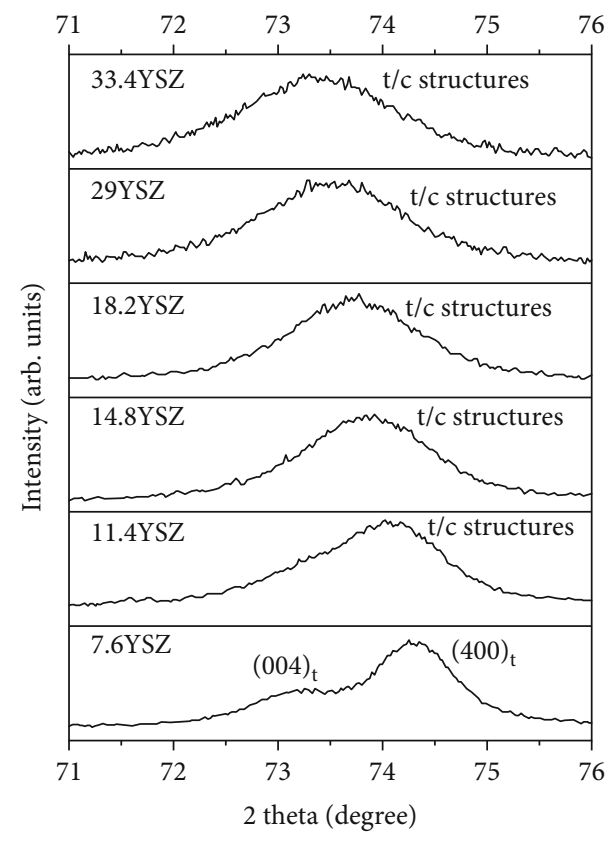

FIgURE 3: XRD patterns of zirconia powders doped with 7.6$33.4 \mathrm{~mol} \% \mathrm{YO}_{1.5}$, heat treated at $700^{\circ} \mathrm{C}$ for $24 \mathrm{~h}$, region $71^{\circ} \leq 2 \theta \leq$ $76^{\circ}$.

the Raman spectra of 29 and 33.4 mol\% yttria heat treated at $700^{\circ} \mathrm{C}$ for 24 and $48 \mathrm{~h}$. As can be seen in Figure $4(\mathrm{a})$, the Raman spectra of zirconia powders with $29 \mathrm{~mol} \%$ yttria (29YSZ) showed five bands located at 146, 261, 319, 465, and $639 \mathrm{~cm}^{-1}$, corresponding to the tetragonal zirconia [42]. On the other hand, the Raman spectrum of zirconia powder doped with $33.4 \mathrm{~mol} \%$ yttria (33.4YSZ) showed an additional broad and intense band at $568 \mathrm{~cm}^{-1}$, which corresponds to the cubic structure of zirconia [42]. This suggests that the YSZ with 29 and $33.4 \mathrm{~mol} \%$ was indeed metastable tetragonal phase $\left(t^{\prime \prime}\right)$ with possibly a mixture of cubic phase for $33.4 \mathrm{~mol} \%$ yttria.

Considering that Yashima and coworkers [24] showed that extended sintering time could promote the stabilization of cubic phase, samples were heat treated up to $48 \mathrm{~h}$. Figure 4(b) shows that the extended sintering time resulted in important changes in the Raman spectra compared to $24 \mathrm{~h}$. For 29 and $33.4 \mathrm{~mol} \%$ yttria, only 2 bands position at 141 and $590 \mathrm{~cm}^{-1}$ were identified, whose similar spectra have been assigned to the cubic phase [42]. This indicates that prolonged heat treatment promoted the diffusion of cations and stabilization of the cubic phase [24].

The phase diagram proposed by Yashima et al. [24] for metastable-stable phases of zirconia (Figure 5) suggests that among the samples produced between 7.6 and $18.2 \mathrm{~mol} \%$ yttria should have resulted in a mixture of monoclinic+cubic phases $(m+c)$ at $700^{\circ} \mathrm{C}$. The presence of a tetragonal $\left(t^{\prime}\right)$ phase instead of a monoclinic+cubic might be possible due to the very small crystallite size of $13.2,10.1,8.9$, and $7.5 \mathrm{~nm}$ for $7.6,11.4,14.8$, and $18.2 \mathrm{~mol} \%$ yttria, whose values are below the $30 \mathrm{~nm}$ value necessary to stabilize this phase even without the presence of yttria [36].

In accordance with our results (for the samples with an extended sintering time), the phase diagram proposed by Yashima et al. predicts that concentrations at $29-33.4 \mathrm{~mol}$ $\%$ yttria should have produced a fully cubic structure. It has been proposed that the stabilization of these metastable phases is achieved by the energy barrier (stabilized by kinetics) rather than the free energy difference, as it takes a long time to achieve a stable phase. This was corroborated with the extended sintering time, which after $48 \mathrm{~h}$, achieved the stabilization of the cubic phase (Figure 4(b)).

3.2. Microstructure and Thickness. It was observed that for coatings with a single deposition, the withdrawal speed did not affect the quality of the coating, since only homogeneous and translucent (only the microstructure of steel was observed) coatings were obtained for all speeds. Conversely, when two layers were deposited, defects were identified using a withdrawal speed of $0.17 \mathrm{~mm} \mathrm{~s}^{-1}$. Nevertheless, it was possible to obtain defect-free coatings with only the steel microstructure visible, with $0.67 \mathrm{~mm} \mathrm{~s}^{-1}$. A similar trend was observed when depositing four layers (Figures 6(a) and 6(b)), where homogeneous coatings were only deposited at $0.67 \mathrm{~mm} \mathrm{~s}^{-1}$ (Figure 6(b)). The formation of a dense and crack-free layer is relevant for its corrosion resistance since it is through the cracks or other defects where water or other corrosive elements can penetrate into the substrate $[19,43]$.

Figure 7 shows the thickness measured by profilometry for coatings with $33.4 \mathrm{~mol} \%$ of yttria in the precursor solution. Overall, thicker layers were obtained with higher withdrawal speeds and the number of layers; for example, the initial coating thickness increased from 226 to 231, 258, and $285 \mathrm{~nm}$ as the withdrawal speed increased to 0.17 , 


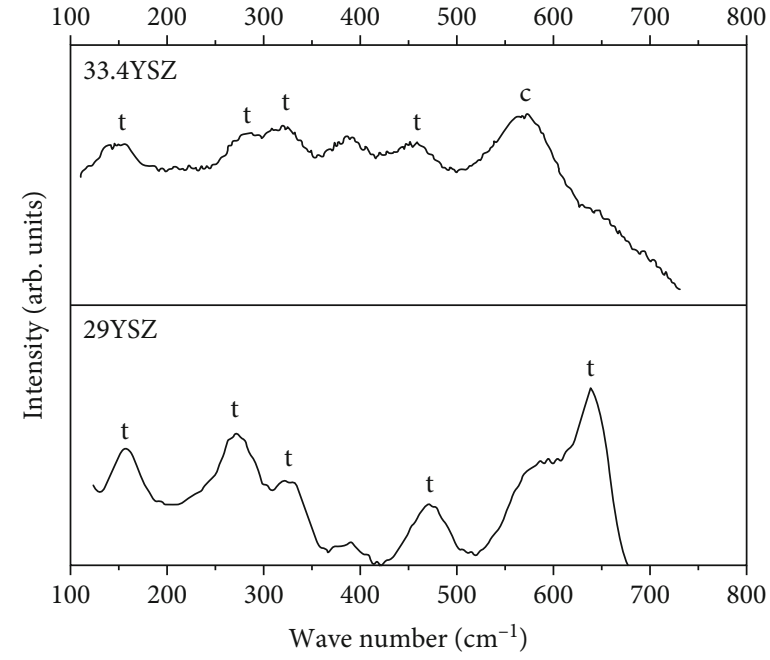

(a)

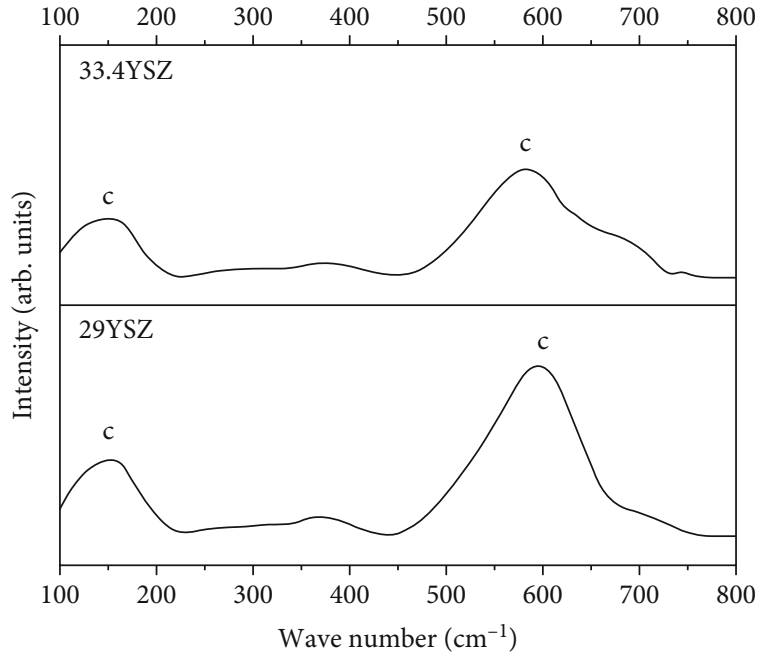

(b)

Figure 4: Raman spectra of zirconia powders doped with 29 and $33.4 \mathrm{~mol} \%$ of yttria and heat treated at $700^{\circ} \mathrm{C}$ for (a) $24 \mathrm{~h}$ and (b) $48 \mathrm{~h}$.

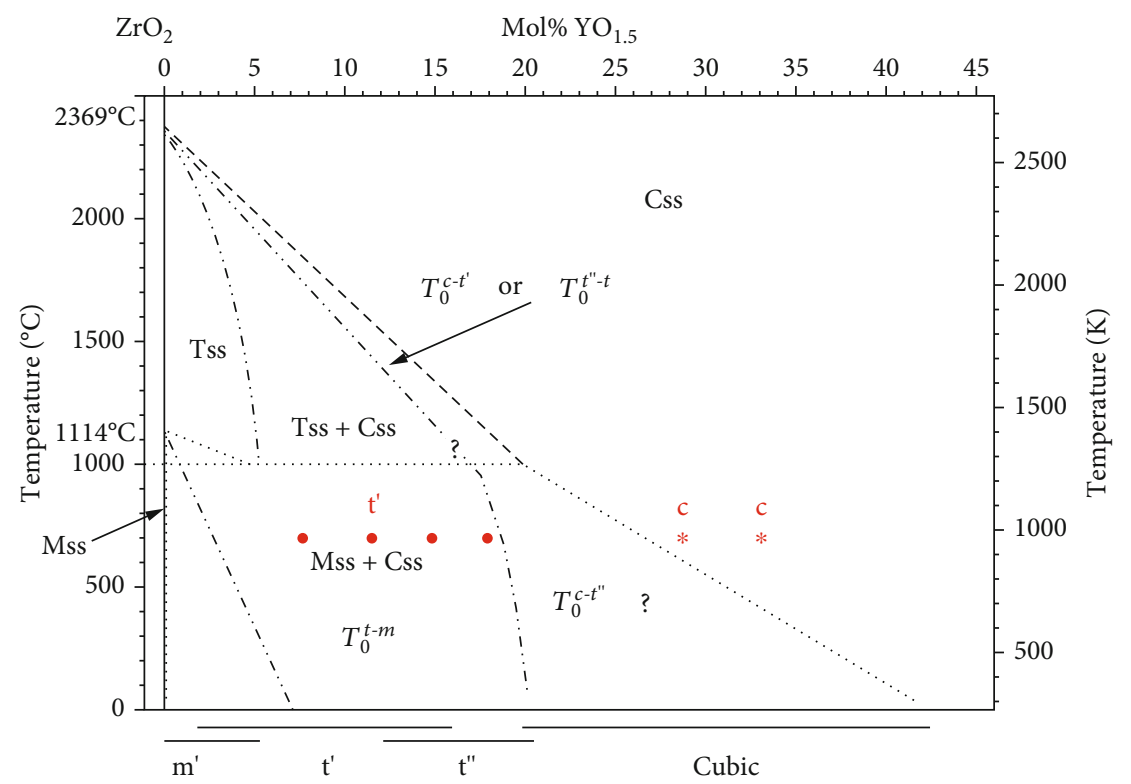

Figure 5: Modified metastable-stable phase diagram of the $\mathrm{ZrO}_{2}$-rich portion in the $\mathrm{ZrO}_{2}-\mathrm{YO}_{1.5}$ system proposed by Yashima and coworkers [24]. Point mark shows the samples produced in this work. The star mark shows the samples sintered at 24 and $48 \mathrm{~h}$. Only the samples sintered for $48 \mathrm{~h}$ produced a fully cubic structure. SS: solid solution; $M$ or $m$ : monoclinic phase; $T$ or $t$ : transformable tetragonal phase; $C$ or $c$ : cubic phase; $t^{\prime}$ : nontransformable tetragonal phase; $t^{\prime \prime}$ : metastable tetragonal phase.

$0.33,0.50$, and $0.67 \mathrm{~mm} \mathrm{~s}^{-1}$, respectively. Coating thickness changed from 226 up to $502 \mathrm{~nm}$ when depositing one and four layers, respectively, with a withdrawal speed of $0.17 \mathrm{~mm} \mathrm{~s}^{-1}$. Similarly, the coating thickness changed from 285 to $824 \mathrm{~nm}$ with one and four layers, respectively, using a withdrawal speed of $0.67 \mathrm{~mm} \mathrm{~s}^{-1}$.

The increase in a single-layer coating thickness of $59 \mathrm{~nm}$ with a withdrawal speed increase from 0.17 to $0.67 \mathrm{~mm} \mathrm{~s}^{-1}$ suggests that the deposition was performed most likely in the intermediate regime [44]. The overall thickness increased with more layers deposited; however, each layer produced a thinner coating. It is likely that the modification of the substrate with a previous YSZ thin film affected the wetting property and adhesion of the fluid on the substrate, as well as the capillary pressure, by modifying the surface tension and the rates of condensation and evaporation [45]. The thickness of the thin films deposited was higher than other reports that showed the production of $970 \mathrm{~nm}$ after 15 deposits using $1 \mathrm{~mm} / \mathrm{s}$ [19] or $130 \mathrm{~nm}$ with 3 layers using $0.5 \mathrm{~mm} / \mathrm{s}$ [43]. The main difference between these reports and the present work is the use of acetic acid instead of acetylacetone. The use of acetic acid tends to promote condensation reactions, in comparison to AcAc, which forms complexes with zirconium propoxide, which are more 


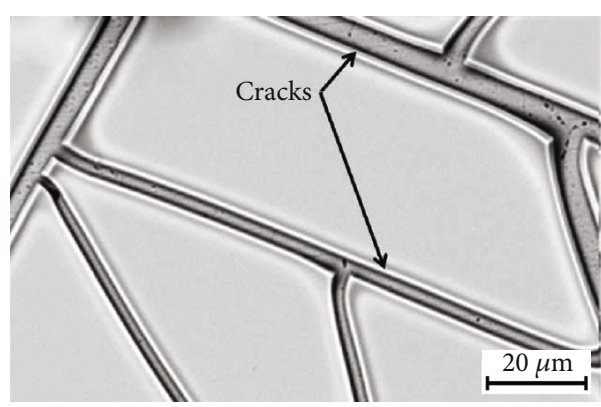

(a)

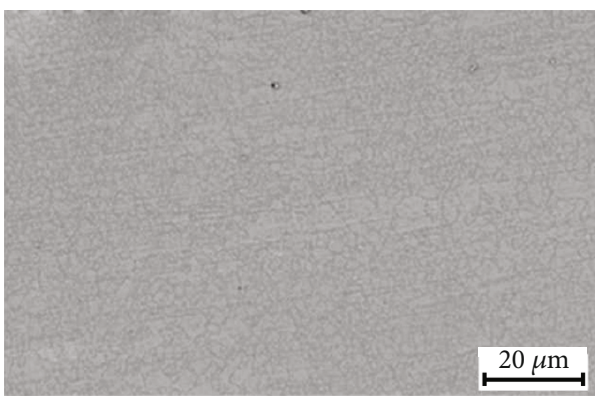

(b)

Figure 6: YSZ thin films heat treated at $700^{\circ} \mathrm{C}$ for $24 \mathrm{~h}$, with four layers deposited using a withdrawal speed of (a) 0.17 and (b) $0.67 \mathrm{~mm} \mathrm{~s}^{-1}$.

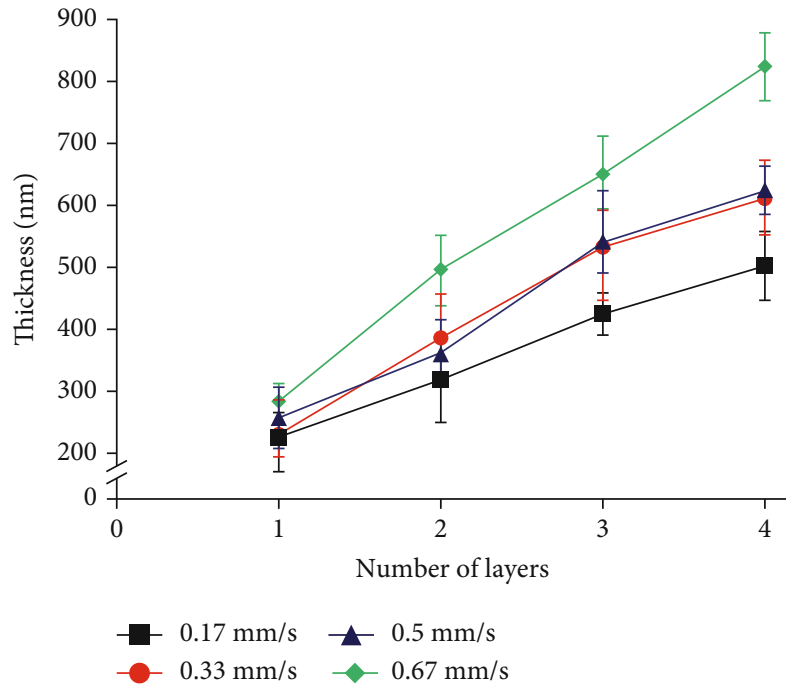

FIGURE 7: Coating thickness of $33.4 \mathrm{YSZ}$ films heat treated at $700^{\circ} \mathrm{C}$ for $24 \mathrm{~h}$, measured by profilometry.

TABLe 2: Results of Pull-Off adhesion strength of 33.4YSZ films on steel $(\mathrm{MPa})$.

\begin{tabular}{lcccc}
\hline $\begin{array}{l}\text { Layers/extraction } \\
\text { rates }\end{array}$ & $\begin{array}{c}0.17 \mathrm{~mm} / \\
\mathrm{s}\end{array}$ & $\begin{array}{c}0.33 \mathrm{~mm} / \\
\mathrm{s}\end{array}$ & $0.5 \mathrm{~mm} / \mathrm{s}$ & $\begin{array}{c}0.67 \mathrm{~mm} / \\
\mathrm{s}\end{array}$ \\
\hline 1 layer & $29.7 \pm 0.5$ & $29.8 \pm 0.8$ & $30.0 \pm 0.5$ & $29.5 \pm 0.6$ \\
2 layers & $29.7 \pm 0.4$ & $29.2 \pm 0.6$ & $29.0 \pm 0.7$ & $29.0 \pm 0.5$ \\
3 layers & $29.0 \pm 0.5$ & $30.2 \pm 0.4$ & $29.2 \pm 0.8$ & $30.2 \pm 0.8$ \\
4 layers & $29.6 \pm 0.7$ & $28.3 \pm 0.6$ & $28.0 \pm 0.8$ & $29.8 \pm 0.7$ \\
\hline
\end{tabular}

difficult to hydrolize, also reducing the condensation process [29].

3.3. Mechanical Properties. The mechanical properties of the 33.4YSZ coatings produced were characterized. Table 2 shows the effect of coating layers and extraction rates on the adhesion strength. All samples showed an adherence strength between 28 and $30 \mathrm{MPa}$. These values are higher than those obtained by sol-gel YSZ on carbon steel (2.512.4 MPa) [17], as well as YSZ deposited by RF magnetron sputtering on $316 \mathrm{~L}$ stainless steel $(12-26 \mathrm{MPa})$ [46]. The adhesion strength was even higher than some YSZ coatings

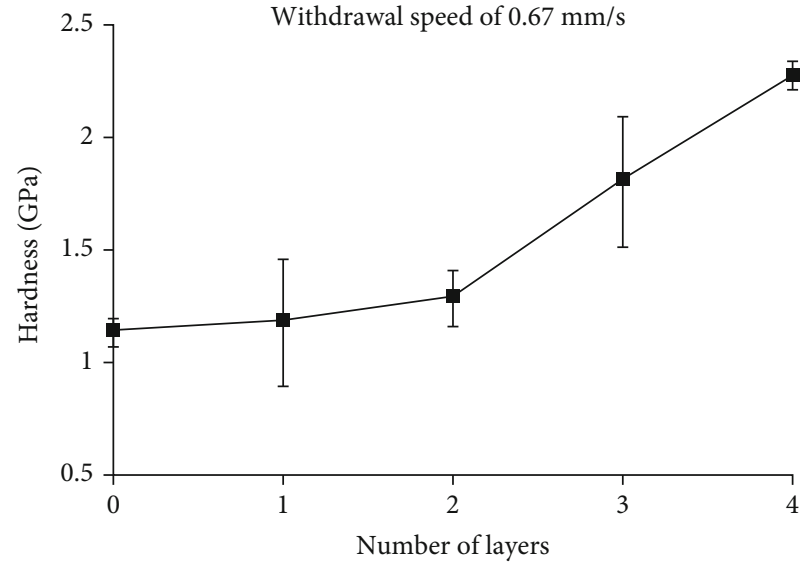

FIGURE 8: Effect of the number of YSZ layers on the hardness of $33.4 \mathrm{YSZ} / \mathrm{steel}$, films heat treated at $700^{\circ} \mathrm{C}$ for $24 \mathrm{~h}$.

produced by plasma spray, which reported values between 15 and $30 \mathrm{MPa}$ [47-49].

The good adherence of the coatings produced at low temperatures has been attributed to a condensation reaction between the alkoxide molecule and the hydroxyl groups on the surface of the metal, resulting in a Zr-O-Fe bond [50]. However, thermogravimetric analysis (TGA) results suggested that at $700^{\circ} \mathrm{C}$, these molecules were already removed, making them an unlikely route of adhesion (Figure 1). Conversely, previous reports have suggested a partial diffusion of $\mathrm{Fe}, \mathrm{Cr}$, and $\mathrm{Ni}$ into $\mathrm{YSZ}$ at the YSZ/steel interface [20, 43, 50]. Therefore, the good adhesion of up to $30 \mathrm{MPa}$ observed in this study could be the result of the prolonged heat treatment (48 hours) at $700^{\circ} \mathrm{C}$, compared with the shorter isotherms generally used during sintering of YSZ coatings for around 1 to 2 hours $[23,26,51]$.

The effect of the coatings on the hardness of the surface (a combination of the hardness of steel and the coating) was also evaluated for $33.4 \mathrm{YSZ}$ coatings deposited at $0.67 \mathrm{~mm} \mathrm{~s}^{-1}$ (Figure 8). Although nanoindentation would have been ideal to characterize these films (not available for this study), microindentation showed that the hardness of the surface increased with every layer deposited, reaching twice the hardness of steel from 1.18 up to $2.28 \mathrm{GPa}$ for four YSZ layers.

The good adherence and mechanical stability of these thin 33.4YSZ layers were also observed by the wear test (Table 3). Our results show that the wear rate decreased 
TABLE 3: Wear rate of 33.4YSZ coated and uncoated steel.

\begin{tabular}{lc}
\hline Sample & Wear rate $\left(\times 10^{-5} \mathrm{~g} / \mathrm{Nm}\right)$ \\
\hline Uncoated & $2.2 \pm 0.1$ \\
1 layer & $2.1 \pm 0.3$ \\
2 layers & $1.9 \pm 0.1$ \\
3 layers & $1.3 \pm 0.2$ \\
\hline
\end{tabular}

$41 \%$ from $2.2 \times 10^{-5} \mathrm{~g} / \mathrm{Nm}$ down to $1.3 \times 10^{-5} \mathrm{~g} / \mathrm{Nm}$ for steel and three layers of YSZ, respectively. These values are similar to those reported for plasma sprayed calcia and magnesia zirconia coatings, which range between 0.6 and $6.25 \times 10^{-5}$ $\mathrm{g} / \mathrm{Nm}$ [52], and slightly higher than other YSZ coatings, with values of $0.14 \times 10^{-6} \mathrm{~g} / \mathrm{Nm}$ [53]. Although in less concentration, EDS elemental maps (see Figure S2 in the supplementary material) showed that zirconia was still present on the surface of steel after the wear test, most likely as the result of the good adherence and higher hardness achieved. Contrary to previous results, the wear rate did not decrease with a higher number of layers [23]. This could be related to the extended sintering time of 48 hours, which promoted the densification and the formation of more crystalline films $[17,26]$.

\section{Conclusions}

Our work stressed the importance of controlling extraction rates and sintering time during the deposition of YSZ coatings through sol-gel dip-coating. In particular, faster extraction rates of $0.67 \mathrm{~mm} \mathrm{~s}^{-1}$ deposited toward the viscous drag regime were needed to achieve uniform coating without apparent surface cracks. This was possibly related to variations in the adhesion and capillary pressure of the solvent on the surface of YSZ compared with steel. We also observed that at $700^{\circ} \mathrm{C}$, it was possible to achieve the thermodynamically stable cubic phase, only after heat treatments of 48 hours, as confirmed by Raman spectroscopy. Moreover, the prolonged heat treatment times improved the mechanical properties of the coatings produced since hardness increased to approximately twice the value of steel (from 1.18 to $2.28 \mathrm{GPa}$ ). Additionally, the deposition and densification of YSZ coatings resulted in a decrease of $41 \%$ in the wear rate. We demonstrated that for low sintering temperatures, such as $700^{\circ} \mathrm{C}, 33.4 \mathrm{~mol} \%$ yttria and 48 hours of heat treatment are needed to achieve maximum crystallinity and cubic phase.

\section{Data Availability}

The data used to support the findings of this study are available from the corresponding author upon request.

\section{Disclosure}

This manuscript has been authored by UT-Battelle, LLC, under contract DE-AC05-00OR22725 with the US Department of Energy (DOE). The US government retains, and the publisher, by accepting the article for publication, acknowledges that the US government retains a nonexclusive, paid-up, irrevocable, worldwide license to publish or reproduce the published form of this manuscript or allow others to do so, for US government purposes. DOE will provide public access to these results of federally sponsored research in accordance with the DOE Public Access Plan (http://energy.gov/downloads/doe-public-access-plan).

\section{Conflicts of Interest}

The authors declare that they have no known competing financial interests or personal relationships that could have appeared to influence the work reported in this paper.

\section{Acknowledgments}

This material is based upon work supported by a grant from CONACYT (project number: 245629, CONACYT-Horizon2020) and forms part of the European project SAMOFAR (A Paradigm Shift in Reactor Safety with the Molten Salt Fast Reactor). The authors would like to acknowledge CONACYT for the MSc and Ph.D. grants awarded to F. J. Cano, O. Castilleja-Escobedo, L. J. Espinoza-Pérez, and C. Reynosa-Martínez.

\section{Supplementary Materials}

Figure S1: TGA curve of YSZ with $33.4 \mathrm{~mol} \% \mathrm{YO}_{1.5}$ (33.4YSZ). Figure S2: EDS elemental maps showing that zirconia was still present on the surface of steel after the wear test. (Supplementary Materials)

\section{References}

[1] J. Wu, J. Chen, X. Kang et al., "A novel concept for a molten salt reactor moderated by heavy water," Annals of Nuclear Energy, vol. 132, pp. 391-403, 2019.

[2] A. R. Shankar, K. Thyagarajan, and U. K. Mudali, "Corrosion behavior of candidate materials in molten $\mathrm{LiCl}-\mathrm{KCl}$ salt under argon atmosphere," Corrosion, vol. 69, no. 7, pp. 655-665, 2013.

[3] V. Firouzdor, J. Brechtl, L. Wilson, B. Semerau, K. Sridharan, and T. R. Allen, "Development of yttrium stabilized zirconia (YSZ) diffusion barrier coatings for mitigation of fuelcladding chemical interactions," Journal of Nuclear Materials, vol. 438, no. 1-3, pp. 268-277, 2013.

[4] P. K. Shukla, E. Hemanth Rao, E. Vetrivendan et al., "Evaluation of plasma sprayed sacrificial thermal barrier coatings for core catcher of future sodium cooled fast reactors," Annals of Nuclear Energy, vol. 107, pp. 31-36, 2017.

[5] T. Dharini, P. Kuppusami, P. Panda, R. Ramaseshan, and A. M. K. Kirubaharan, "Nanomechanical behaviour of $\mathrm{Ni}$ YSZ nanocomposite coatings on superalloy 690 as diffusion barrier coatings for nuclear applications," Ceramics International, vol. 46, no. 15, pp. 24183-24193, 2020.

[6] L. J. Espinoza-Pérez, E. López-Honorato, and L. A. González, "Development of $\mathrm{ZrO}_{2}$ and $\mathrm{YSZ}$ coatings deposited by PECVD below $800{ }^{\circ} \mathrm{C}$ for the protection of Ni alloys," Ceramics International, vol. 46, no. 10, pp. 15621-15630, 2020. 
[7] K. Mo, G. Lovicu, X. Chen, H. M. Tung, J. B. Hansen, and J. F. Stubbins, "Mechanism of plastic deformation of a Ni-based superalloy for VHTR applications," Journal of Nuclear Materials, vol. 441, no. 1-3, pp. 695-703, 2013.

[8] B. A. Thiele, F. Schubert, H. Derz, and G. Pott, "Influence of test temperature on post irradiation, high temperature tensile and creep properties of X8 CrNiMoNb 1616, X10 NiCrAlTi 3220 (Alloy 800) and $\mathrm{NiCr}_{22} \mathrm{Fe}_{18} \mathrm{Mo}$ (Hastelloy X)," Journal of Nuclear Materials, vol. 171, no. 1, pp. 94-102, 1990.

[9] D. S. Aidhy, Y. Zhang, and W. J. Weber, "Radiation damage in cubic $\mathrm{ZrO}_{2}$ and yttria-stabilized zirconia from molecular dynamics simulations," Scripta Materialia, vol. 98, pp. 16-19, 2015.

[10] J. M. Costantini, F. Beuneu, and W. J. Weber, "Radiation damage in cubic-stabilized zirconia," Journal of Nuclear Materials, vol. 440, no. 1-3, pp. 508-514, 2013.

[11] K. E. Sickafus, H. Matzke, T. Hartmann et al., "Radiation damage effects in zirconia," Journal of Nuclear Materials, vol. 274, no. 1-2, pp. 66-77, 1999.

[12] A. Debelle, S. Moll, B. Décamps et al., "Ability of cubic zirconia to accommodate radiation damage," Scripta Materialia, vol. 63, no. 6, pp. 665-668, 2010.

[13] P. Stefanov, D. Stoychev, I. Valov, A. Kakanakova-Georgieva, and T. Marinova, "Electrochemical deposition of thin zirconia films on stainless steel 316 L," Materials Chemistry and Physics, vol. 65, no. 2, pp. 222-225, 2000.

[14] Y. Pan, J. H. Zhu, M. Z. Hu, and E. A. Payzant, "Processing of YSZ thin films on dense and porous substrates," Surface and Coatings Technology, vol. 200, no. 5-6, pp. 1242-1247, 2005.

[15] P. Lenormand, D. Caravaca, C. Laberty-Robert, and F. Ansart, "Thick films of YSZ electrolytes by dip-coating process," Journal of the European Ceramic Society, vol. 25, no. 12, pp. 26432646, 2005.

[16] C. Viazzi, J. P. Bonino, and F. Ansart, "Synthesis by sol-gel route and characterization of yttria stabilized zirconia coatings for thermal barrier applications," Surface and Coatings Technology, vol. 201, no. 7, pp. 3889-3893, 2006.

[17] M. A. Domínguez-Crespo, A. García-Murillo, A. M. TorresHuerta, F. J. Carrillo-Romo, E. Onofre-Bustamante, and C. Yáñez-Zamora, "Characterization of ceramic sol-gel coatings as an alternative chemical conversion treatment on commercial carbon steel," Electrochimica Acta, vol. 54, no. 10, pp. 2932-2940, 2009.

[18] A. Zarkov, A. Stanulis, J. Sakaliuniene et al., "On the synthesis of yttria-stabilized zirconia: a comparative study," Journal of Sol-Gel Science and Technology, vol. 76, no. 2, pp. 309-319, 2015.

[19] S. Rezaee, G. R. Rashed, and M. A. Golozar, "Electrochemical and oxidation behavior of yttria stabilized zirconia coating on zircaloy-4 synthesized via sol-gel process," International Journal of Corrosion, vol. 2013, 9 pages, 2013.

[20] R. L. Winter, P. Singh, M. K. King, M. K. Mahapatra, and U. Sampathkumaran, "Protective ceramic coatings for solid oxide fuel cell (SOFC) balance-of-plant components," Advances in Materials Science and Engineering, vol. 2018, Article ID 9121462, 17 pages, 2018.

[21] C. Viazzi, A. Deboni, J. Zoppas Ferreira, J. P. Bonino, and F. Ansart, "Synthesis of yttria stabilized zirconia by sol-gel route: influence of experimental parameters and large scale production," Solid State Sciences, vol. 8, no. 9, pp. 1023-1028, 2006.
[22] J. Sniezewski, Y. LeMaoult, P. Lours et al., "Sol-gel thermal barrier coatings: optimization of the manufacturing route and durability under cyclic oxidation," Surface and Coatings Technology, vol. 205, no. 5, pp. 1256-1261, 2010.

[23] W. Zhang, G. Ji, A. Bu, and B. Zhang, "Corrosion and tribological behavior of $\mathrm{ZrO} 2 \mathrm{Films}$ prepared on stainless steel surface by the sol-gel method," ACS Applied Materials \& Interfaces, vol. 7, no. 51, pp. 28264-28272, 2015.

[24] M. Yashima, M. Kakihana, and M. Yoshimura, "Metastablestable phase diagrams in the zirconia-containing systems utilized in solid-oxide fuel cell application," Solid State Ionics, vol. 86-88, pp. 1131-1149, 1996.

[25] J. Fenech, C. Viazzi, J. P. Bonino, F. Ansart, and A. Barnabé, "Morphology and structure of YSZ powders: comparison between xerogel and aerogel," Ceramics International, vol. 35, no. 8, pp. 3427-3433, 2009.

[26] S. K. Tiwari, J. Adhikary, T. B. Singh, and R. Singh, "Preparation and characterization of sol-gel derived yttria doped zirconia coatings on AISI 316L," Thin Solid Films, vol. 517, no. 16, pp. 4502-4508, 2009.

[27] W. Liu, Y. Chen, C. Ye, and P. Zhang, "Preparation and characterization of doped sol-gel zirconia films," Ceramics International, vol. 28, no. 4, pp. 349-354, 2002.

[28] E. Courtin, P. Boy, C. Rouhet et al., "Optimized sol-gel routes to synthesize yttria-stabilized zirconia thin films as solid electrolytes for solid oxide fuel cells," Chemistry of Materials, vol. 24, no. 23, pp. 4540-4548, 2012.

[29] S. G. Kim, S. W. Nam, S. P. Yoon et al., "Sol-gel processing of yttria-stabilized zirconia films derived from the zirconium nbutoxide-acetic acid-nitric acid-water-isopropanol system," Journal of Materials Science, vol. 39, no. 8, pp. 2683-2688, 2004.

[30] M. T. Soo, N. Prastomo, A. Matsuda et al., "Elaboration and characterization of sol-gel derived $\mathrm{ZrO}_{2}$ thin films treated with hot water," Applied Surface Science, vol. 258, no. 13, pp. 52505258, 2012.

[31] R. Shoja Razavi and M. R. Loghman-Estarki, "Advance techniques for the synthesis of nanostructured zirconia-based ceramics for thermal barrier application," in Sol-gel Based Nanoceramic Materials: Preparation, Properties and Applications, A. Mishra, Ed., Springer, Cham, 2016.

[32] D. R. Clarke and S. R. Phillpot, "Thermal barrier coating materials," Materials Today, vol. 8, no. 6, pp. 22-29, 2005.

[33] C. W. Kuo, Y. H. Lee, K. Z. Fung, and M. C. Wang, "Effect of $\mathrm{Y}_{2} \mathrm{O}_{3}$ addition on the phase transition and growth of YSZ nanocrystallites prepared by a sol-gel process," Journal of Non-Crystalline Solids, vol. 351, no. 4, pp. 304-311, 2005.

[34] D. D. Upadhyaya, M. R. Gonal, and R. Prasad, "Studies on crystallization behaviour of $3 \mathrm{Y}-\mathrm{TZP} / \mathrm{Al}_{2} \mathrm{O}_{3}$ composite powders," Materials Science and Engineering A, vol. 270, no. 2, pp. 133-136, 1999.

[35] S. Gutzov, J. Ponahlo, C. L. Lengauer, and A. Beran, "Phase characterization of precipitated Zirconia," Journal of the American Ceramic Society, vol. 77, no. 6, pp. 1649-1652, 1994.

[36] R. C. Garvie, "The occurrence of metastable tetragonal zirconia as a crystallite size effect," The Journal of Physical Chemistry, vol. 69, no. 4, pp. 1238-1243, 1965.

[37] R. Srinivasan, R. J. De Angelis, G. Ice, and B. H. Davis, "Identification of tetragonal and cubic structures of zirconia using synchrotron x-radiation source," Journal of Materials Research, vol. 6, no. 6, pp. 1287-1292, 1991. 
[38] C. Viazzi, J. P. Bonino, F. Ansart, and A. Barnabé, "Structural study of metastable tetragonal YSZ powders produced via a sol-gel route," Journal of Alloys and Compounds, vol. 452, no. 2, pp. 377-383, 2008.

[39] H. G. Scott, "Phase relationships in the zirconia-yttria system," Journal of Materials Science, vol. 10, no. 9, pp. 1527-1535, 1975.

[40] A. Feinberg and C. H. Perry, "Structural disorder and phase transitions in $\mathrm{ZrO}_{2}-\mathrm{Y}_{2} \mathrm{O}_{3}$ system," Journal of Physics and Chemistry of Solids, vol. 42, no. 6, pp. 513-518, 1981.

[41] M. Yashima, K. Ohtake, M. Kakihana, H. Arashi, and M. Yoshimura, "Determination of tetragonal-cubic phase boundary of Zr1-XRXO2-X2 ( R = Nd, Sm, Y, Er and $\mathrm{Yb}$ ) BY Raman scattering," Journal of Physics and Chemistry of Solids, vol. 57, no. 1, pp. 17-24, 1996.

[42] Y. Hemberger, N. Wichtner, C. Berthold, and K. G. Nickel, "Quantification of yttria in stabilized zirconia by Raman spectroscopy," International Journal of Applied Ceramic Technology, vol. 13, no. 1, pp. 116-124, 2016.

[43] I. Bačić, H. Otmačić Ćurković, L. Ćurković, V. Mandić, and Z. Šokčević, "Corrosion protection of AISI 316L stainless steel with the Sol- Gel yttria stabilized $\mathrm{ZrO}_{2}$ films: effects of sintering temperature and doping," International Journal of Electrochemical Science, vol. 11, no. 11, pp. 9192-9205, 2016.

[44] M. Faustini, B. Louis, P. A. Albouy, M. Kuemmel, and D. Grosso, "Preparation of sol-gel films by dip-coating in extreme conditions," Journal of Physical Chemistry C, vol. 114, no. 17, pp. 7637-7645, 2010.

[45] C. J. Brinker, G. C. Frye, A. J. Hurd, and C. S. Ashley, "Fundamentals of sol-gel dip coating," Thin Solid Films, vol. 201, no. 1, pp. 97-108, 1991.

[46] Z. E. Sánchez-Hernández, M. A. Domínguez-Crespo, A. M. Torres-Huerta, E. Onofre-Bustamante, J. Andraca Adame, and H. Dorantes-Rosales, "Improvement of adhesion and barrier properties of biomedical stainless steel by deposition of YSZ coatings using RF magnetron sputtering," Materials Characterization, vol. 91, pp. 50-57, 2014.

[47] R. Ghasemi and H. Vakilifard, "Plasma-sprayed nanostructured YSZ thermal barrier coatings: thermal insulation capability and adhesion strength," Ceramics International, vol. 43, no. 12, pp. 8556-8563, 2017.

[48] J. Wang, J. Sun, H. Zhang et al., "Effect of spraying power on microstructure and property of nanostructured YSZ thermal barrier coatings," Journal of Alloys and Compounds, vol. 730, pp. 471-482, 2018.

[49] R. Vert, P. Carles, E. Laborde, G. Mariaux, E. Meillot, and A. Vardelle, "Adhesion of ceramic coating on thin and smooth metal substrate: a novel approach with a nanostructured ceramic interlayer," Journal of Thermal Spray Technology, vol. 21, no. 6, pp. 1128-1134, 2012.

[50] M. J. Filiaggi, R. M. Pilliar, and D. Abdulla, "Evaluating sol-gel ceramic thin films for metal implant applications. II. Adhesion and fatigue properties of zirconia films on Ti-6Al-4V," Journal of Biomedical Materials Research, vol. 33, no. 4, pp. 239-256, 1996.

[51] S. K. Tiwari, M. Tripathi, and R. Singh, "Electrochemical behavior of zirconia based coatings on mild steel prepared by sol-gel method," Corrosion Science, vol. 63, pp. 334341,2012 .
[52] M. A. E. Hafez, S. A. Akila, M. A. Khedr, and A. S. Khalil, "Improving wear resistance of plasma-sprayed calcia and magnesia-stabilized zirconia mixed coating: roles of phase stability and microstructure," Scientific Reports, vol. 10, no. 1, article 78088, 2020.

[53] D. Kumar and K. N. Pandey, "Experimental investigations of sol-gel process parameters for wear reduction on thermal barrier coated AA2024 aluminum alloys with the use of Taguchibased optimization," Sādhanā, vol. 45, no. 1, 2020. 